\title{
El teatro y la memoria emergente de El Mariel: Testimonio, vulnerabilidad y archivo
}

\author{
Mariel Martínez Alvarez \\ University of Michigan, Ann Arbor, US \\ marielma@umich.edu
}

\begin{abstract}
En el presente artículo analizo dos obras de teatro Diez millones (2017) de la compañía "Argos Teatro" y el performance Departures, de la compañía Habanera "El Ciervo Encantado". Propongo que estas obras usan el registro testimonial para narrar los actos de repudio desde el niño, o adolescente en formación, que fueron durante los años ochenta. Desde un presente situado después de El Periodo Especial, los protagonistas pueden reflexionar sobre su propia memoria y la manera en la que ha impactado sus vidas. La centralidad de los niños, la incomprensión de los actos en los que están participando y la exposición de su vulnerabilidad facilita que la audiencia se identifique con ellos. Más aún, permite borrar la pregunta por la responsabilidad puesto que los niños tenían muy poco margen para decidir cómo actuar cuando ya la comunidad revolucionaria había decidido cuáles serían sus roles. A este procedimiento enunciativo y performativo es lo que llamaré una "vulnerabilidad estratégica" que permite al teatro reformular el concepto de la pertenencia, exclusión y repudio en el contexto del antagonismo durante los ochentas. Las obras de teatro que abordan los actos de repudio hacen emerger estos marcos sociales de la memoria que involucran: el relato testimonial desde la vulnerabilidad del niño que realiza el acto de repudio, su impacto en el presente y al mismo tiempo, las ideas del documento y el archivo como una posibilidad de recuperar la memoria. De estos elementos, emerge el marco de la memoria que permite permitan comenzar a habitar la memoria del Mariel.
\end{abstract}

Keywords: teatro; testimonio; memoria; repudio; vulnerabilidad

\author{
"Los actos de repudio han sido como una sombra, \\ por donde quiera que pasó la revolución, \\ pasó el acto de repudio." \\ -Rafael Alcides, entrevista del documental Gusanos
}

Durante mi primera estancia de investigación en la Habana, muchas noches caminé por el malecón desde La Habana Vieja hasta donde comenzaba Vedado. Algunas veces la gente me saludaba y me preguntaba por mi nombre, que es poco común en la isla: “¿Márien? ¿Marlen?" No, respondía yo, "Mariel, como el puerto." Entonces me preguntaban "¿qué puerto?", a lo que yo respondía con alguna precisión geográfica: "como a una hora, yendo rumbo a Santa Fe." Ocurrió un par de veces hasta que dejé de hacer la aclaración. La mayoría de los que me preguntaron eran personas jóvenes y esto me hizo pensar... El éxodo de 1980, ¿quiénes lo recuerdan en Cuba? Y más aún, ¿cómo lo recuerdan y por qué lo recuerdan de esa manera? Antes de conocer Cuba, me había preguntado cuál sería la recepción de un escritor como Reinaldo Arenas, específicamente de su libro de memorias, Antes que anochezca (1992). Me di cuenta de que la recuperación de la memoria en Cuba es un proceso reciente y que todavía hacía falta tiempo para recordar El Mariel y los actos de repudio de los ochenta desde la incómoda desnudez del testimonio. Esos actos de repudio que, promovidos por el gobierno revolucionario, consistieron en humillar públicamente a quienes querían irse gritándoles insultos, leyendo comunicados, lanzándoles piedras, huevos, etc, llamándoles "escoria" y "gusanos." Tal vez, pensé otra vez, es 
demasiado pronto para hablar de la memoria histórica de los actos de repudio. Sin embargo, en el teatro cubano contemporáneo ya es posible identificar algunas estrategias para que la memoria pueda emerger. ${ }^{1}$ Ulises Rodríguez Febles ofrece la primera reflexión escenificando los actos de repudio en su obra de teatro Huevos, estrenada en el 2004. A esa obra, siguieron otras que compartieron elementos similares con ésta. Por lo tanto, es pertinente comenzar a preguntarse: ¿Cómo las producciones culturales están comenzando a contar y, en consecuencia, a generar un imaginario y un archivo en torno a los eventos de 1980? ¿Cuáles son los lenguajes que utilizan para filtrar los eventos históricos para recuperar el pasado en torno a los actos de repudio?

En el presente artículo analizo la obra de teatro Diez millones, de Carlos Celdrán (n. 1963), un director y dramaturgo habanero que dirige la compañía "Argos Teatro." Analizo también el performance Departures, de la compañía habanera "El Ciervo Encantado." Estas obras ocurren en un presente situado en el siglo XXI, después de El Período Especial y desde ahí, los personajes recuerdan cómo tuvieron que repudiar a sus conocidos, amigos y familia cuando eran niños (o adolescentes en formación). Los protagonistas usan un registro testimonial para exponer la incomprensión y la vulnerabilidad de los niños que fueron lo cual lleva a la audiencia a generar un lazo fuerte de simpatía e identificación. En ese sentido, la escenificación de la vulnerabilidad es una estrategia para generar simpatía hacia las personas que realizaron los actos de repudio.

En el contexto caribeño, Guillermina de Ferrari ha analizado la vulnerabilidad como un sitio productivo con respecto a la memoria y a la resistencia frente al legado colonial. ${ }^{2}$ Uno de sus casos de estudio aborda los relatos de la infancia y comenta el papel de la responsabilidad entre el autor de la obra y sus lectores:

By reading the story of a child who is immersed in a culturally if not physically violent situation, we naturally tend to want to side with the child-narrator, whom we cannot hold responsible for the state of affairs engulfing him or her. In and by the very foundation on which this - childhood stories- genre is constructed, both the author and the reader remain in a safe place guarded by the figure of the child-observer and the reader's seemingly unproblematic identification with him or her. The affable nature of the reading contract it establishes with its public would alone seem to account for the genre's popularity in the Caribbean today. (De Ferrari 105-106)

La pregunta por la responsabilidad, que es central para entender el relato de un niño en formación, toma una dimensión diferente en la especificidad política y cultural de la Cuba revolucionaria. En el teatro contemporáneo de El Mariel, la vulnerabilidad infantil es una estrategia para poder hablar de las pérdidas, las exclusiones y la separación familiar durante 1980. Es estratégica porque se centra en el dolor y en la incomprensión para opacar la responsabilidad histórica de los actores políticos quienes concibieron el acto de repudio como una vía para la revolución deseada. ${ }^{3}$ A este procedimiento enunciativo y performativo es lo que llamaré una "vulnerabilidad estratégica." Estas vulnerabilidades estratégicas son una búsqueda por formas de existir en común que interrumpen la práctica del repudio y que intentan repensar la historia y la memoria desde un marco de memoria nuevo, que nace desde la necesidad de entender por qué las pérdidas y qué significaron.

\section{Diez millones: la memoria desperdiciada de lo que fuimos}

Diez millones es la primera obra escrita y dirigida por Carlos Celdrán, ${ }^{4}$ fundador y director de la compañía Argos Teatro en 1996. Hasta el estreno de Diez millones, Argos Teatro había llevado a la escena libretos de escritores cubanos que no pertenecían a la compañía. Diez millones ha sido la obra que les ha garantizado

\footnotetext{
${ }^{1}$ Aquí estoy siguiendo la definición de Ann Rigney de los marcos de memoria emergentes: "that is, social frameworks that are defined, not by ethnic descent or other inherited identities, but by ongoing acts of affiliation based on common values and aspirations that offer a new perspective on the past" (373).

${ }^{2}$ Específicamente, De Ferrari propone la figura de la niña en formación lo cual implica la creación de un cuerpo que repite el esquema de subyugación y de domesticidad: "In other words, if both boyhood and girlhood stories provide an innocent point of ethnographic observation of colonial societies, the girl, as opposed to the boy, tends to expose the way in which these societies are formed and preserved by denouncing the extent to which her own body is implicated in the incorporation and perpetuation of colonialism" (107).

${ }^{3}$ Para más información sobre los procesos culturales que crearon el deseo de la revolución en la población Cubana, se puede consultar el libro de Pedro Porbén.

${ }^{4}$ Celdrán es licenciado en Dramaturgia por el Instituto Superior de Artes Escénicas. Comenzó su carrera trabajando como asesor dramático para Teatro Buendía, y tiempo después, comienza a escribir y dirigir obras de teatro de manera independiente con su Argos Teatro. Sus obras se han presentado en Cuba, Latinoamérica, Estados Unidos y Europa.
} 
visibilidad a nivel internacional. ${ }^{5}$ Es una reflexión con un tono autobiográfico y confesional desde la perspectiva de un adolescente cuir que intenta navegar el optimismo revolucionario de los setenta. El personaje "Madre" es una revolucionaria convencida con un alto cargo en una institución revolucionaria y "Padre" es un hombre de pueblo que nunca se adaptó a los cambios políticos. "Él", que es el protagonista, afirma que sus padres se divorciaron a causa de "algo oscuro" relacionado consigo mismo. Tanto el padre, un hombre tradicional, como la madre, que lucha por convertirlo en un hombre revolucionario, intenta corregir su "falta de firmeza" llevándolo a terapia, a las escuelas de campo, a los internados de voluntariado, inscribiéndolo a clases de boxeo, etc. En un mundo en el que no tiene lugar para pertenecer en términos políticos, familiares y de género, el protagonista se sorprende a sí mismo participando en un acto de repudio contra su propio padre, quien se refugia en la embajada del Perú para intentar pedir la salida hacia Estados Unidos. Unos años después, Madre también decide emigrar y el protagonista se queda sólo en la isla, en donde se ha convertido en dramaturgo. El personaje que abre y cierra la obra es "Autor." Cuando Diez Millones comienza, "Autor" aparece en el escenario y comenta que está en Nueva York durante 2001, escribiendo una obra de teatro para comprender quiénes fueron sus padres. Por lo tanto, la audiencia reconoce que los personajes "Madre" $\mathrm{y}$ "Padre" son los recuerdos de su familia, son los recuerdos que "Autor" tiene de ellos y que "El", el adolescente que protagoniza la obra, es el recuerdo que tiene "Autor" cuando era joven.

Tuve oportunidad de ver la obra en La Habana en el 2017. No recuerdo exactamente cómo llegué a saber que Argos Teatro estaba presentando una obra en su sede, localizada en Ayestarán número 307. Era la última función de la temporada. La avenida Ayestarán era mucho más larga de lo que había pensado y aunque conseguí llegar antes de que la función comenzara, las entradas ya se habían agotado. Me senté en un banco enfrente de la sala de teatro a lamentar mi falta de precaución ${ }^{6}$ y un señor vino a decirme que la compañía había decidido hacer una representación más el próximo domingo a las cinco de la tarde. El domingo siguiente llegué a la sala a las 3:30pm, se hizo una larga fila para comprar las entradas y se volvieron a agotar rápidamente. Esta vez, pude entrar a ver la obra. La sala de Argos Teatro es pequeña y cuadrada: tiene una capacidad para alrededor de setenta personas, el escenario de medio cajón está muy cerca de la primera línea de sillas, las siguientes líneas están escalonadas para que el espectador pueda ver mejor. Carlos Celdrán entró al escenario e hizo una breve presentación antes de que la obra comenzara. Mencionó que la función de ese día era una ocasión especial porque Argos Teatro estaba celebrando sus 20 años de trayectoria y que, por esta razón, la puesta en escena se filmaría para archivos y la memoria de la compañía. Esa sensación de celebración y de estar siendo parte del registro archivístico se podía percibir entre los actores, quienes trabajaron con una energía inesperada, y entre la audiencia, que nos fuimos contagiando con la intensidad y de la puesta en escena. Cuando la obra terminó, los aplausos fueron inmediatos y continuaron durante mucho más tiempo que lo que habrían durado en una puesta en escena regular: a veces parecían terminar, pero luego volvían a ganar intensidad y así estuvimos aplaudiendo durante varios minutos.

Las notas al programa que nos entregaron al entrar a la sala ya preparaban al espectador para una puesta con tono íntimo y testimonial:

Diez millones fue un texto escrito en distintos momentos a través de los años. Nació como diario personal hasta llegar a ser lo que es ahora, un material para la escena, un tejido de narraciones, diálogos, monólogos, donde se intenta lo más arriesgado en el teatro: partir de uno mismo para hablar a otros, a todos. Su escritura busca desesperadamente, a través de las distintas voces que articula, saber qué fuimos, de qué materiales estuvo hecha la mezcla que nos sostiene.

La escritura de un individuo que pretende hablar a todos es un procedimiento retórico del género testimonial. Como destaca Linda Marie Brooks, "Rather than verifiable truth claims, the witness's and editor's words are enactments of broader truths - performances of the dialogical process by which truths originate" (126). En Diez Millones, "saber qué fuimos" comprende una reflexión colectiva en donde la verdad de "Él" es también la verdad de una generación que vivió los años del optimismo revolucionario.

\footnotetext{
${ }^{5}$ La obra se presentó en 2017 en: La Habana, Ciudad de México, Los Angeles, Nueva York y Miami. En 2018 se estrenó en Washington, DC, en el Kennedy Center. Y en 2019 se presentó de nuevo en la XIII Bienal de La Habana, y en el Festival Internacional de Cine de Gibara.

${ }^{6}$ Tiempo después, leyendo el libro de Bretton White y sus reflexiones auto etnográficas me recordaron lo difícil que puede ser participar como audiencia en un evento teatral.
} 
Las notas al programa continúan aclarando que la obra fallará al momento de originar estas verdades testimoniales:

es una interpretación del pasado, de su oscuridad, de lo incierto e incongruente del pasado. De aquellos que fuimos y que ya no entendemos. Los otros muchos que éramos y que luego enterramos para sobrevivir. Cada día reinventamos nuestras biografías y olvidamos la anterior en una amnesia colectiva que mira el presente sin vínculos con aquello que pensábamos antes. Podría intentar definir Diez millones como un relato sobre el olvido, sobre la memoria desperdiciada de lo que fuimos.

Estas notas en el programa preparan al espectador para un espectáculo impreciso, pero también para una representación innecesaria, con un tono pesimista sobre lo que la memoria no puede recuperar o sobre la inutilidad de lo que la memoria puede recuperar.

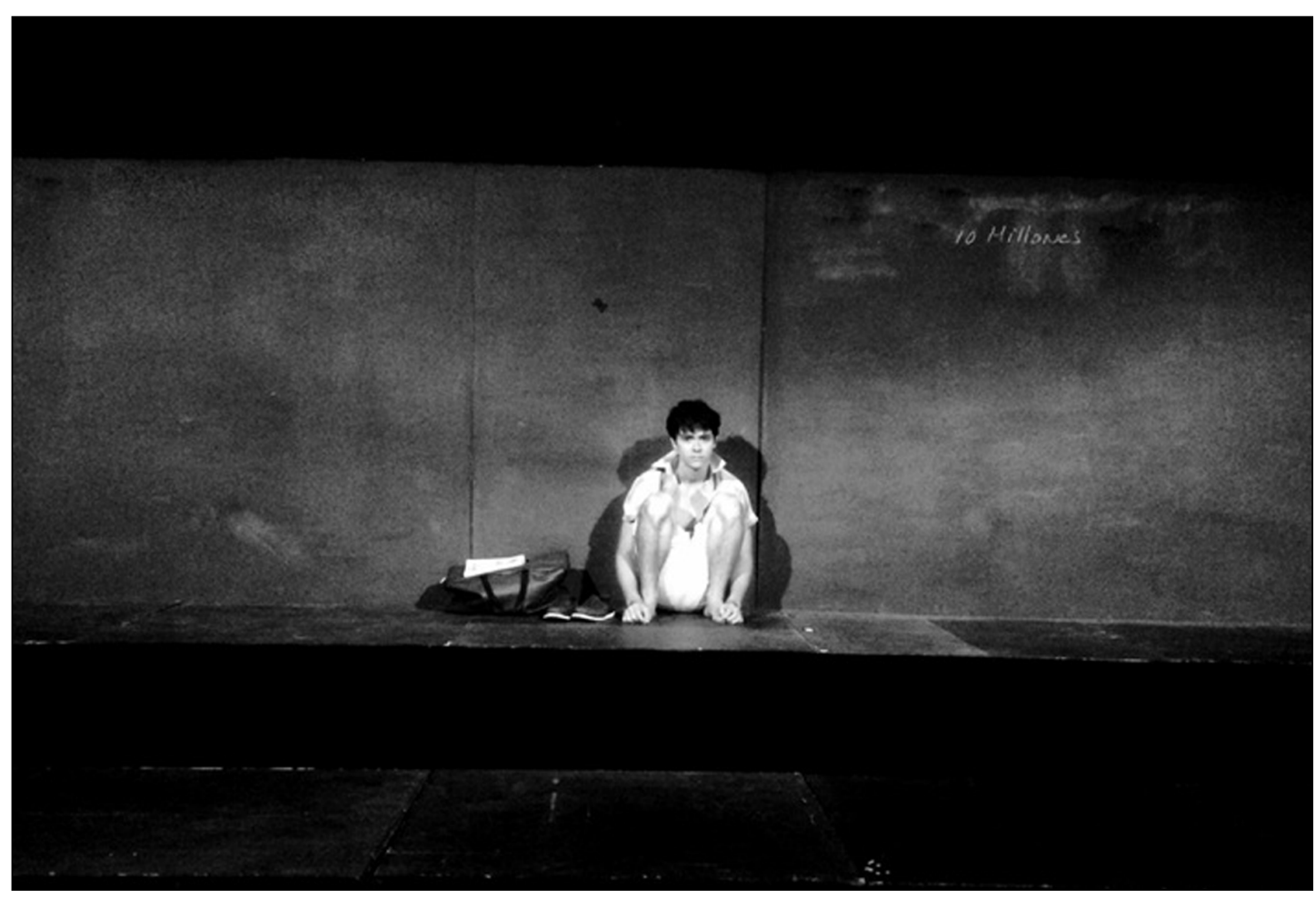

Fotografía en las notas al programa. Archivo personal.

"Él" aparece al centro de la composición como un cuerpo indefenso y vulnerable. Se agarra sus pies desnudos, recogiéndose a sí mismo, como si no tuviera derecho a habitar en donde está. Lleva una maleta y unos zapatos, indicando que no tiene un lugar seguro donde existir, es decir, indica la falta de hogar. En la composición, no hay nadie más que Él y tampoco hay nada, además de la maleta. Esto habla del aislamiento y de la desposesión que el personaje sufrió durante su vida, no sólo de lo que no tiene en ese entonces, sino de lo que no va a poder tener. ${ }^{7}$ Está en el centro del escenario con las luces que lo presentan como si estuviera asistiendo a un interrogatorio. La pregunta que tiene que contestar es (esto fue lo que pensé volviendo a mirar el programa después de la obra) por qué no puedes ser lo que la revolución imaginó para ti. Por qué te esfuerzas suficiente por ser un "hombre de verdad."

\footnotetext{
${ }^{7}$ La falta de lugar en el mundo representada a través de la falta de objetos también la encontramos en el poema, "Vestido de Novia" de Norge Espinosa: "Con qué espejos / con qué ojos / va a retocarse las pupilas este muchacho que alguna vez quiso llamarse Alicia / que se justifica y echa la culpa a las estrellas / con qué estrellas con qué astros podrá mañana adornarse los muslos / se los va a sostener / con qué pluma va a escribir su confesión ay este muchacho / vestido de novia en la "oscuridad."
} 


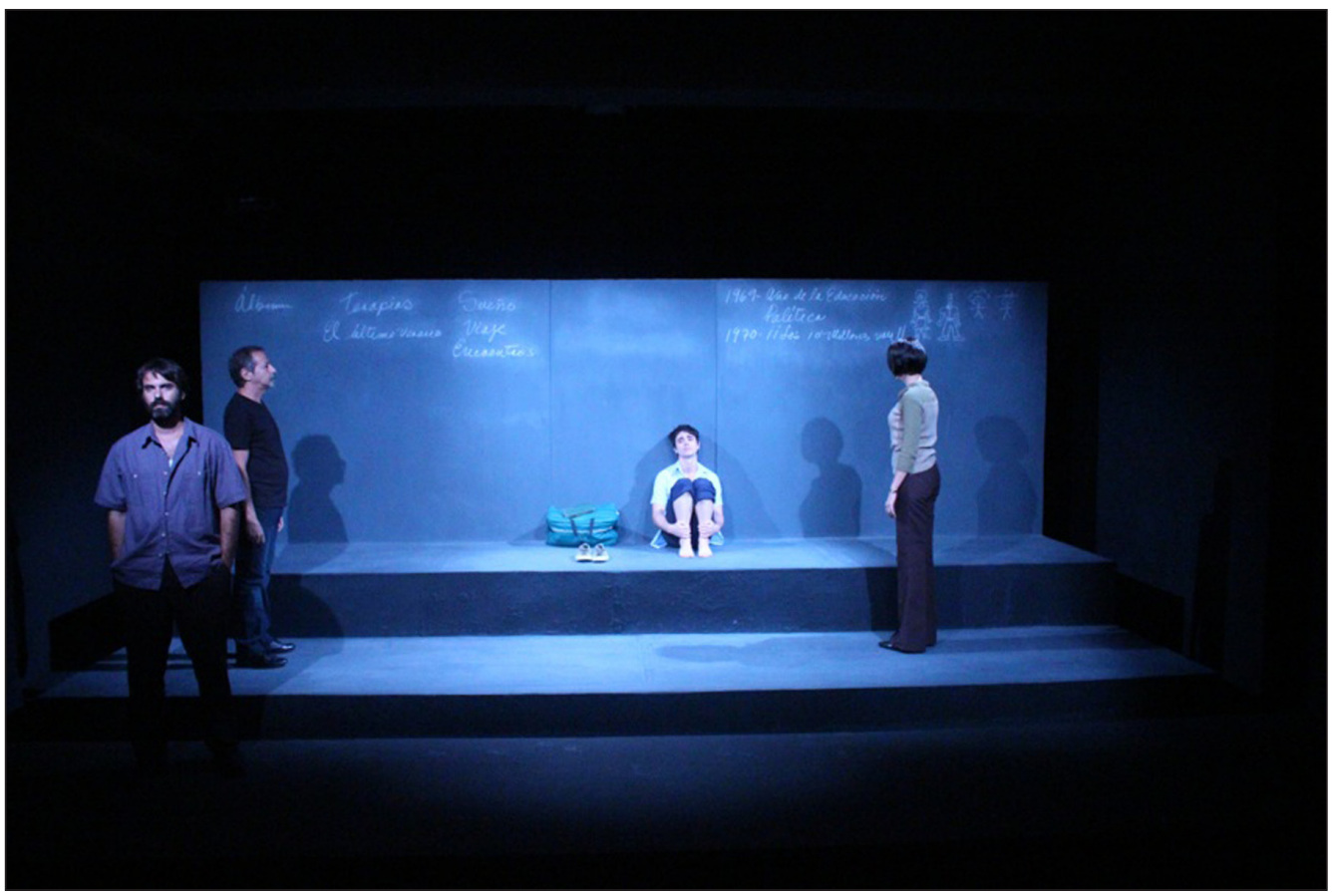

Manolo Garriga. “Fotografía de Diez Millones”, 2016.

El escenario es muy simple: está compuesto únicamente por una tarima y un pizarrón, en donde "Él" escribe y dibuja. En el lado izquierdo escribe palabras relacionadas con su vida personal: "sueño", "viaje", "encuentro", "terapias". En la derecha, las diferentes periodizaciones de la historia revolucionaria.

En el escenario, los actores interpretan a personajes que se encuentran en dos tiempos diferentes: en los setenta y a principios del siglo veintiuno. Los actores escenifican las acciones y los diálogos del pasado y, al mismo tiempo, reflexionan sobre ellos con largos soliloquios en el presente de la obra. Los diálogos de los personajes (en cursivas en el guión), ocurren durante los sesenta hasta los ochenta. Principalmente, son órdenes, gritos, peleas que los actores pronuncian en un tono de voz muy alto. Las reflexiones, pensamientos y explicaciones sobre los eventos son soliloquios que los personajes enuncian con tono reflexivo y dubitativo. Por lo tanto, la audiencia asiste a una extraña combinación temporal en donde el mismo autor reflexiona sobre lo que está haciendo. Incluso algunos diálogos vuelven a repetirse como si el protagonista los estuviera volviendo a recordar, dándoles otro enfoque y otra interpretación. La combinación de soliloquios y diálogos demuestra el proceso de funcionalización implícito en el acto de recordar.

La obra retrata los intentos de una familia por corregir el afeminamiento de su hijo y los esfuerzos del protagonista cuir para navegar los modelos de pertenencia y masculinidad que entraron fuertemente en contradicción durante los años del optimismo revolucionario. Para Madre y para Padre, "Él" es un cuerpo maleable porque se encuentra en formación, es decir, en proceso de convertirse en un adulto, y también es un cuerpo que debe ser corregido. El protagonista cuenta cómo sus padres discuten su comportamiento: "Yo los oigo. Siempre lo oigo todo. Lo que pasa. Lo que miran en mí. Empiezan a vigilarme, a hacerme preguntas raras. Sé desde el primer momento las respuestas a esas preguntas y no respondo, los confundo. También hay regaños: baja las manos, no hables así, no manotees, no juegues con eso, sal a la calle. No hago caso (785). "Él" necesita deshacerse de "lo que miran en él". Los padres intentan disciplinar el movimiento de las manos, el tono de voz, la preferencia por ciertos objetos. El padre sigue un modelo heteronormativo y patriarcal de la masculinidad e intentará corregir su comportamiento a través de la proximidad con él como figura paterna. La madre, comprometida con la revolución, realizará varios intentos por convertirlo en un "verdadero revolucionario" a través de terapias, del trabajo en la Zafra de los Diez Millones ${ }^{8}$ y, finalmente, lo inscribe en una escuela al campo. Sobre el afeminamiento en la revolución Abel Sierra Madero destaca:

\footnotetext{
${ }^{8}$ La Zafra de los Diez Millones fue una etapa en la historia de la industria azucarera cubana en la que el gobierno se propuso producir diez millones de toneladas de azúcar entre 1969 y 1970. En los discursos sobre la zafra intersectaron la retórica de servicio a la patria, el optimismo del desarrollismo agrario y las repeticiones de cifras numéricas como indicador principal del bienestar revolucionario. La meta no se llegó a cumplir y el evento queda en el imaginario cubano como un trauma irresuelto sobre las contradicciones del servicio a la patria, el enaltecimiento del trabajo físico y la libertad individual.
} 
La narrativa que se producía sobre el afeminamiento en el niño generalmente culpaba a los padres y a la familia. Las hipótesis más recurrentes desplegadas por los psicólogos sugerían que la ausencia del padre era un fundamental y que el afeminamiento generalmente estaba asociado a la histeria y la sobreprotección de la madre. El niño afeminado era considerado dentro de una lógica familiar educativa fallida, así se justificaba la intervención del Estado y la necesidad de su estudio, su rehabilitación y la corrección de sus gestos. La idea sobre el deporte, el trabajo rudo y la sociabilidad en ambientes masculinos para torcer los destinos del niño o sujeto afeminado, tomó mucha fuerza en ese momento. (Notas al programa 330)

Por esta razón, el cuerpo de "Él" se vuelve un campo de batalla en el que Madre, Padre, los médicos, los maestros y demás actores intentarán corregir el problema de su comportamiento.

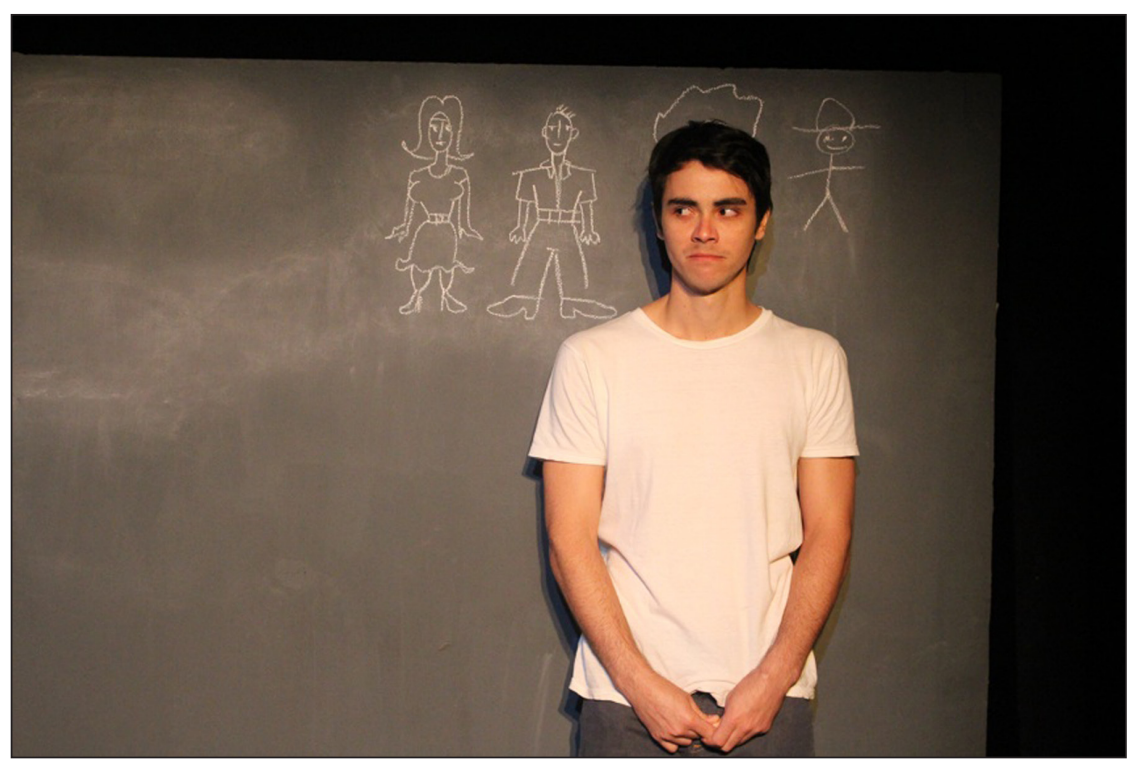

Manolo Garriga, “Fotografía de Diez Millones”, 2016.

En esta fotografía, que se usó para la portada de la revista Tablas vol. CIX en donde apareció por primera vez la versión impresa del guión, "Él" en terapia debe realizar el examen de Machover, ${ }^{9}$ dibujando a una mujer y a un hombre para determinar si la ausencia del padre ha influido su comportamiento.

La explicación del afeminamiento de "Él" como una consecuencia de una condición psicológica tiene de fondo la lógica de la rehabilitación que intenta reincorporar al individuo a la comunidad. Tanto la psicología, como la educación y, en cierta medida, la familia, destacan en la obra como instituciones complementarias en la creación de la comunidad revolucionaria. ${ }^{10}$ Este proceso de higiene social encontró su máxima expresión en el concepto de "rehabilitación", el cual justificó el trabajo forzado como un método de corrección para la homosexualidad. La psiquiatría y la psicología se usaron en los campos de trabajo y en las Unidades Militares de Ayuda a la Producción (de mediados a finales de los años sesenta) como laboratorios para desarrollar y explorar la relación entre las condiciones socioambientales y la homosexualidad. ${ }^{11}$ Se condujeron entrevistas, experimentos y evaluaciones en las unidades, así también, las unidades se utilizaron como una manera de disciplinar las conductas no-productivas: "The revival of occupational therapy resonated with an official

\footnotetext{
${ }^{9}$ Esta fue la conclusión de un estudio hecho con la prueba de Machover "dibuja a una persona". Esta prueba fue usada con dos grupos de cien hombres, uno formado por heterosexuales y otro por homosexuales. Los investigadores notaron la predominancia de los dibujos femeninos en el grupo de los hombres homosexuales y concluyeron que la homosexualidad representaba un "mecanismo inadecuado de identificación sexual" que estaba relacionado con la "valoración excesiva del rol femenino" (Lambe 124). La traducción es mía/. This was the conclusion of a study in which the Machover ("draw a person") test was applied to two groups of one hundred heterosexual and homosexual men. Noting the predominance of female figures in the drawings of the homosexual group, the investigators concluded that homo sexuality represented an "inadequate ... mechanism of sexual identification," linked to the "overvaluation of the feminine role" (Lambe 124).

${ }^{10}$ En su Breve ensayo sobre la psicología en Cuba, Manuel Calviño destaca: "La integración de la Psicología en Cuba como una 'ciencia profesional' como una 'actuación científica profesional' ha sido la condición misma de su origen, su desempeño y el sentido mismo de su ejercicio como disciplina comprometida con un proyecto social que la trasciende. Que trasciende incluso a Cuba" (12).

${ }^{11}$ Para una relación pormenorizado sobre el trabajo de investigación desarrollado por las unidades psiquiátricas en las UMAP, se puede consultar el libro de Jennifer L. Lambe.
} 
emphasis on the redemptive value of voluntary work and the importance of manual labor to individual and communal identity" que tenía también beneficios económicos puesto que:

the universal application of unpaid labor promised to forge a new generation of revolutionaries free of 'selfish tendencies,' even as it rehabilitated Cubans stained by the bourgeois past. In the words of Che Guevara, an influential member of the latter group, voluntary work was the element that most actively [developed] the workers' conscience, preparing the road to a new society. (Lambe 150-151)

El segundo intento de Madre para corregir el comportamiento de su hijo es cuando lo lleva a participar en la zafra siguiendo la lógica de corrección a través del trabajo duro:

Hambre, mucha hambre, un pan, una bandeja de calamina, arroz, potaje, agua con azúcar, siempre hambre, siempre hombres con caras prietas, máscaras. Son máscaras. No veo caras de verdad, lavadas, limpias, no veo cómo son esas caras. Nunca. Se van a otra zafra, desaparecen. No hay tiempo para descansar, amanecemos allí, en las cabinas, en pleno campo, ila zafra de los diez millones! Veo lo que es la terapia. (Notas al programa 789)

La idea del anonimato que marca a los hombres que no tienen una cara propia y el nomadismo se presentan ante el personaje como sujetos intercambiables. Las condiciones de los trabajadores, el constante esfuerzo físico y la abstracción de zafra de los diez millones constituyen una realidad ajena sobre la cual "Él" no puede construir relaciones de pertenencia. La energía colectiva, la rutina y la precariedad están descritas bajo la óptica del automatismo y de la homogeneidad. La zafra de los diez millones y la imposibilidad de pertenencia del protagonista en el contexto del trabajo colectivo es un recordatorio sobre el fracaso de las empresas revolucionarias en el plano económico y de la construcción de la comunidad en torno a estos objetivos comunes. Sin embargo, considerando la relación entre psiquiatría, rehabilitación, homosexualidad y trabajo duro, Diez millones es una obra que usa el espacio de la zafra para cuestionar el concepto de rehabilitación, que fue central para la articulación de la comunidad revolucionaria durante la década de los sesentas y setentas.

Finalmente, Madre manda al protagonista a una escuela al campo en donde "Él" conoce a un muchacho al que los otros compañeros del campamento desprecian por tener la cara llena de acné. Ahí crean una relación de cuidado mutuo y el protagonista puede sentirse por primera vez entendido por alguien. Él describe:

Al año siguiente, el segundo curso allí, llega con la cara limpia, sin acné, sin granos, los ojos se ven, son grandes. Cae en la litera a mi lado, es muy blanco, le salen manchas en la piel que debe curar con una poción, no le llegan las manos a la espalda, hasta donde están las manchas y me pide ayuda. Yo froto las manchas en su espalda con un algodón, me mancho los dedos con la poción amarilla que huele a hierro, a azufre. Es algo entre él y yo, las manchas amarillas en los dedos, mi sacrificio. Lo hacemos cuando no hay nadie cerca, a veces en el baño, en los inodoros. (791)

Este acto en común está basado en la complicidad y en el secreto. A diferencia de los trabajadores en la zafra, que tienen máscaras negras, en lugar de estar manchados con tierra, sus manos están manchadas con amarillo para curarlo y esta diferencia es también una diferencia creativa. Mientras que la tierra está relacionada con la productividad y el trabajo, la pócima amarilla tiene una connotación creativa, de posibilidad y de exploración que puede estar relacionada con la composición de una pintura. "Él" ya puede ver la cara y los ojos del otro que únicamente se le revela a él en el acto íntimo de curar la piel del otro. Por lo tanto, es en la complicidad y en la vulnerabilidad compartida que el protagonista puede crear una existencia con el otro, basada en la relación de necesidad.

Mientras pasa el tiempo en la escuela, la relación se intensifica frente a los ojos de los otros compañeros:

Parecen hermanos dicen los otros. Él no responde, pero siente orgullo de que nos vean hermanos. Aprendemos eso allí, la lealtad, escondidos del trabajo, fugados por el campo, bajo la lluvia, sol, comiendo naranjas para llenarnos, compartiendo el jabón, la ropa, las botas, la peste, la fiebre, los chistes. No aprendo allí nada más que eso. No aprendo otra cosa que él. No tengo nada mío, una muda sucia para la semana, El Rojo y el Negro. Lo demás me lo robaron. Estaba él. (791)

A través de este acto en común, la obra está proponiendo una lealtad basada en la semejanza, el placer y la necesidad. De esta manera el protagonista suspende las relaciones de la comunidad revolucionaria y en su lugar emerge un espacio donde puede existir y pertenecer. Lo demás, son relaciones de exclusión que lo 
dejan como un extraño, en un mundo que le es ajeno. En este mundo ajeno, el protagonista es incapaz de aprender "nada más que eso", ni aprende "otra cosa que él." "Eso" y "él", son pronombres cuyo significado depende de la situación del hablante y, por lo tanto, acarrean indeterminación y ambigüedad. Esta imposibilidad de nombrar con precisión aquello que está aprendiendo nos sitúa de nuevo en el contexto del lenguaje homoerótico en donde el personaje no puede o no quiere nombrar su deseo.

El padre también intenta corregir a su hijo, pero lo hace a través del contacto continuo con él: "mi padre quiere que viva un tiempo con él en el pueblo, en su casa del pueblo, es una solución, un padre real, un ejemplo para un niño con problemas, yo tengo problemas" (785). Sin embargo, la relación que mantiene con el Padre es una relación ambigua entre el disciplinamiento y el refugio del dinamismo de los cambios sociales en la capital. La relación entre Padre y "Él" tiene momentos de complicidad y de proximidad emocional que prefigura la relación que tendrá con el muchacho de la escuela al campo. Conforme pasa el tiempo y el orden social cambia, Padre decide que es tiempo de irse a Estados Unidos por el Mariel. "Él" sabe que Padre está entre los ocupantes de la embajada, pero la experiencia es la que mira en las imágenes y "Él" percibe la toma de la Embajada como un evento deplorable: "La televisión pasa el día entero imágenes de la Embajada ocupada, repleta de gente, cuentan cómo los primeros en entrar lo hicieron matando a un custodio. No paro de mirar esas imágenes, las miro mientras las repiten y no entiendo qué tienen que ver conmigo, con él" (794). Las imágenes poseen modelos de cómo los estudiantes deben comportarse, lo que deben pensar y cómo deben de conformar una comunidad. La repetición auditiva y el automatismo también juega un papel importante:

Coreo con los demás cada condena, cada consigna, indignado de lo que veo, de lo que escucho que está sucediendo, algo inaudito, sin precedentes. Convencido de eso. Molesto de lo que pasa, allí, en las imágenes. Lo desagradable de aquellas secuencias, de aquellas caras. Caras tan distintas a la de mi padre. No lo relaciono. No obstante, sé que no debo hablar. Pero no lo relaciono. No entiendo. (794)

Por lo tanto, el protagonista se convierte en sus compañeros y sale a marchar para participar en los actos de repudio. Esto es una interrupción de la dicotomía entre el sujeto y el "otro" que está dentro de la embajada, puesto que el sujeto cuir, el sujeto "no-revolucionario" es el que repudia a los ocupantes. El 7 de abril de 1980, el Granma publicó una editorial que caracterizaba a los ocupantes de la embajada como lumpens, delicuentes y escoria, explicando que dentro de la embajada había muchos homosexuales y que "cada vez más las fronteras entre el delincuente común y el contrarrevolucionario se confunden" (4). Esa escisión entre el "otro", "Él" y el sujeto se ve en las reflexiones del acto frente a la embajada:

\begin{abstract}
Él marcha hasta llegar a la embajada y reflexiona: Al estar justo frente a la fachada de la Embajada, tantas veces vista en esos días en la televisión, una conmoción corre por entre el grupo que está a mi lado, el verla en directo, al compás de los himnos que salen de los altavoces, con mucho más volumen ahora que estamos en el sitio, produce un estremecimiento compacto, profundo, en bloque, en todos nosotros, que hace que al unísono levantemos las manos y gritemos con furia desconcertante, sorpresiva. También yo grito, de modo inesperado, automático, grito, vuelvo a gritar lo que gritan, lo que tenemos que gritar. Lo que nos han dicho que gritemos. Lo que se grita allí. (795)
\end{abstract}

El personaje no se reconoce a sí mismo en sus acciones porque ya forma parte del "bloque". La energía de los actos de repudio. En ese momento, la posibilidad de reconocer la cara de su padre, lo devuelve a los patrones de pertenencia que tenía con él. Las relaciones familiares deshacen la uniformidad del repudio y dejan al protagonista en un espacio intersticial:

De pronto, recuerdo, bajo las manos, dejo de gritar, una reacción que ninguno a mi alrededor ve ni entiende. Al momento siguiente recuerdo que lloro, por mi padre dentro y fuera, por aquellos gritos que doy, que dan, por el desprecio, por esa emoción que nos une y nos aleja, por no ser y ser ellos, distante y unido a eso, a eso que pasa y no debe pasar, que desprecio y apoyo, lloro y el llanto borra las últimas imágenes de la fachada de la Embajada. (795)

La organización social producida por el performance del odio crea una dicotomía que el protagonista identifica en ese momento: yo afuera, él adentro, yo maltrado, él condenado. Sara Ahmed señala que el performance público y colectivo del odio en donde el "otro" es una amenaza para "el nosotros": 
Hate is involved in the very negotiation of boundaries between selves and others, and between communities, where 'others' are brought into the sphere of my or our existence as a threat. This other, who may stand for or stand by others, presses against me, threatening my existence. (51)

Sin embargo, la vulnerabilidad emerge cuando el protagonista se ve en la posibilidad de ver y ser visto. La posibilidad del reconocimiento del otro lo desliga del performance del odio colectivo dejando al protagonista en un espacio intersticial en donde se encuentra solo. Deja de pertenecer a "el gentío" y, al mismo tiempo, deja de pertenecer a la lógica de la familia.

La inconsistencia entre las dos formas de pertenencia lo deja sin un país porque el episodio termina cuando el protagonista comienza a llorar y las lágrimas borran la imagen de la fachada de la embajada.

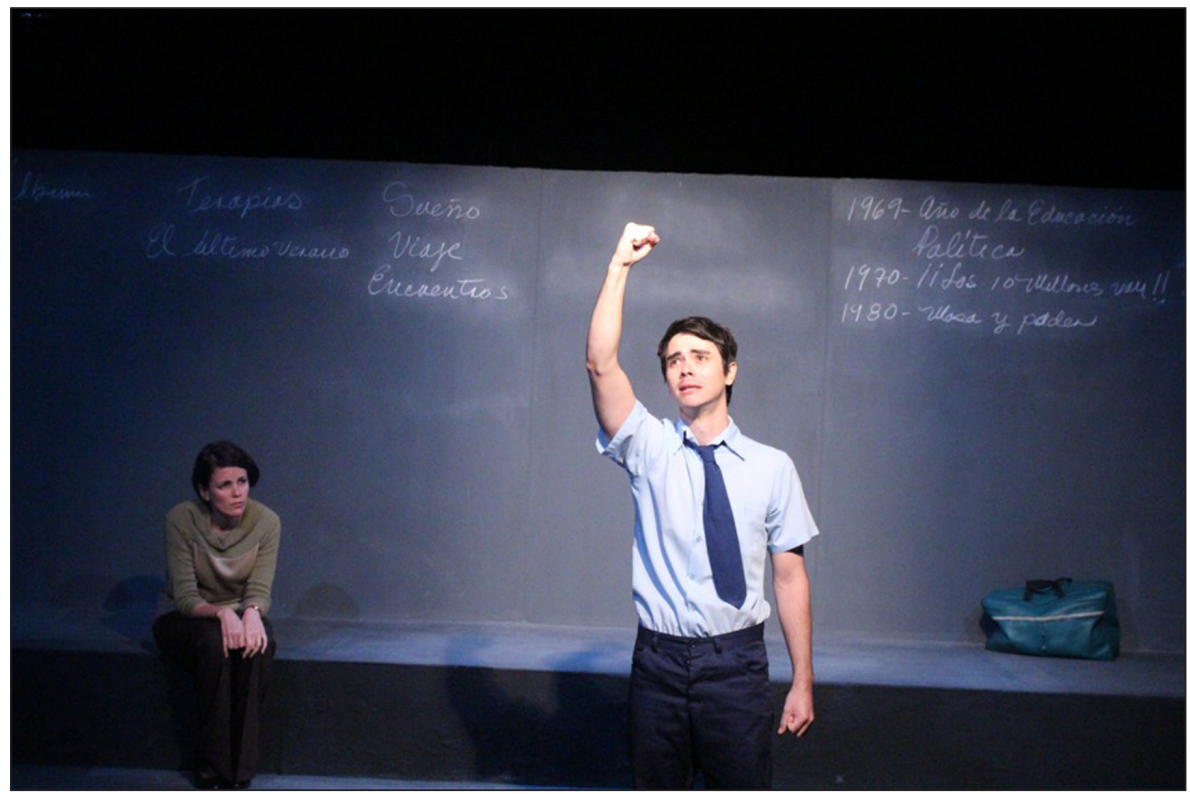

Manolo Garriga. "El acto de repudio frente a la embajada”, 2016.

En esta imagen el cuerpo del actor se mueve para demostrar su oposición a los otros que se encuentran en la embajada. Sin embargo, el gesto de su cara interrumpe el performance público del odio. Aunque el cuerpo está repitiendo el automatismo que ha aprendido en la beca con otros estudiantes, la cara revela cómo sus acciones están en contra de sus intereses.

Tal y como las lágrimas borran la fachada de la embajada, el tiempo borra la escritura en el pizarrón, el cambio borra la conexión con los documentos del pasado. Entonces su madre reflexiona sobre las ventajas del olvido para poder continuar con la vida: "Hasta hoy, me piden volver a hablar de aquello. ¿Qué tengo que decir, en realidad? ¿Qué cosa evocar? Puedo reconstruir algo, hechos, quizás algunas ideas en juego, sin embargo, son ideas del pasado, ya superadas, que solo puedo rehacer, dramatizar ahora para ustedes. Y cuando haces esto, no son las ideas, las grandes ideas políticas que fueron, son fantasmas de ideas" (276). La obra se presenta como una pregunta que los actores se reúsan a contestar. Lo mismo ocurre con los documentos personales de los personajes: cuando la madre mira un álbum de fotografías de su juventud, destaca: "Son fotos extrañas. De desconocidos. De estos dos que veo aquí. Fotos de ellos. No nuestras. De dos desconocidos que no somos ya" (786). Más adelante, la reflexión de la madre continúa:

Son fotos divertidas. Donde ella se divierte. Estoy segura que se divierte. Es joven. Y es libre por primera vez. Es ella. La que fue. La auténtica ella. En el cénit de su vida. Feliz. La de esos años. La que realmente fui. La que ya no puedo ser. Ni deseo ser. (790)

Tanto los diálogos, los documentos, la escritura y, en general, la historia son materiales inestables a la hora de intentar entender lo que pasó durante los años del optimismo revolucionario. Diez Millones, aunque es un relato testimonial en donde los registros de la vulnerabilidad y el dolor son centrales, también es una reflexión sobre los peligros del olvido y la posibilidad de vivir en un pasado que se reconoce como verdadero pero ajeno al mismo tiempo. 
En una entrevista sobre la puesta en escena en Nueva York, Carlos Celdrán comentó sobre la recepción de Diez millones en Cuba:

La reacción es semejante a la que percibiste en Nueva York. No tengo palabras, ni quiero usarlas, para definirla, solo te digo que no es la reacción que esperas con el teatro, es otra cosa, y esa otra cosa que pasa me deja mudo, perplejo, también agradecido. La mayoría de la gente me dice que mi historia es su historia, que jamás pensaron que sus vidas podían tener interés, y que al ver la obra descubren que estaban equivocados, de lo cual concluyo que el pasado lo asumimos como algo irrelevante, a olvidar, a enterrar. Y es un gravísimo error, pues lo que hemos vivido es lo más importante que se espera contemos. (Del Risco)

En La Habana, Diez millones ha sido bien recibida por la audiencia y por los organismos oficiales. La revista Casa de las Américas describe la obra como una mezcla de varios géneros: "El acto confesional, el teatro documental, lo autoficcional mezclado a una suerte de biografía resultan el centro de la acción dramática de la pieza" (108). La indistinción entre la ficción y la realidad, la idea de la indeterminación y de una historia que todavía se está escribiendo es una estrategia del autor para comenzar el diálogo en torno a los actos de repudio, el patriotismo y al disciplinamiento de las subjetividades no normativas. La reseña continúa:

Llevada a escena por su autor, con magníficas actuaciones, Diez millones cuestiona, inquiere, incomoda al lector o al espectador ante nociones como patriotismo y colectivismo (...) Iniciado a partir de la escritura de un diario personal, el texto refiere diversas etapas de la historia colectiva, como la zafra azucarera del 70, cuya meta era lograr los diez millones de toneladas, de ahí el título de la pieza. La alusión a ese hecho concreto se torna en mecanismo para reconstruir un pasado personal tornado en memoria colectiva, a veces lacerada por el olvido, pero necesaria. (109)

Aunque la reseña, publicada por una institución oficial no aborda la subjetividad cuir del protagonista que no consigue crear relaciones de pertenencia, el debate de la necesaria recuperación de la memoria está comenzando a generarse desde los canales oficiales. Un aspecto que facilita la circulación de la obra es que el protagonista nunca se identifica como un sujeto cuir. Usa un lenguaje que mezcla los diálogos de sus padres, parafrasea lo que ellos han dicho y, a veces, se confunden con sus propios pensamientos y recuerdos. En otras ocasiones, el protagonista recurre a un lenguaje más poético para hablar de la identificación y el deseo. Por lo tanto, la imprecisión poética, la imprecisión de la memoria y la reproducción de un sentimiento de la culpa inculcado por su familia y su contexto político, crean una ambigüedad que permite a la audiencia ignorar, hasta cierto punto, el deseo homoerótico que marca el testimonio en Diez Millones.

\section{Departures: el huevo que me habían puesto en la mano}

El performance Departures, trata los momentos más grandes de emigración a partir del testimonio de la actriz Mariela Brito (n. 1968). En el escenario, Mariela ${ }^{12}$ camina entre sillas que tienen fotos y cartas de las personas que se han ido de la isla. Usando únicamente el movimiento de sus manos y un tono de voz que intenta contener el dolor detrás de las historias, Departures resulta una poderosa intervención en la memoria de la migración, específicamente, de la separación familiar. La cronología de la obra abarca desde el inicio de la revolución de 1959: primero por vuelos regulares, luego por Camarioca, pasando por El Mariel, hasta llegar a la crisis de los balseros, en 1993, cuando Brito emigró a México y regresó en 1994. La obra termina con un video corto de fotografías relacionadas a todos estos momentos e incluye momentos sobre las migraciones del siglo XXI de los cubanos por Latinoamérica.

El Ciervo Encantado es una compañía fundada en 1996 por Nelda Castillo (n. 1953), antes directora en el Teatro Buendía. ${ }^{13}$ Mariela Brito es la actriz principal de la compañía y el asesor es Jaime Gómez Triana (n. 1978). El Ciervo Encantado nace como un espacio de búsqueda que se sigue manteniendo en las obras más

\footnotetext{
${ }^{12}$ Me referiré a la actriz usando su nombre completo. Cuando hable del personaje de Departures, utilizaré únicamente su nombre de pila.

13 Sobre la fundación de El Ciervo Encantado, Nelda Castillo señala: "Se fundó en el 96 con la graduación de mis alumnos de ese año. Hicimos una obra que se llamaba así, El ciervo encantado, de Borrero Echeverría. Era una obra de la memoria cubana, de la Guerra de Independencia-una analogía realmente de la Guerra de Independencia. Y yo gradué a mis alumnos con ese cuento. El Ciervo Encantado simbolizaba la libertad, la necesidad de cazar a un ciervo que no se dejaba cazar. Un ciervo muy difícil de cazar, era símbolo de la libertad y también, para nosotros, de identidad. Por eso se funda en el 96 con ese cuento homónimo. El primer cuento editado en Cuba en 1905 y lo tomamos como premisa, como base de sentido, de concepto para el grupo: cazar la identidad. En esa cacería comenzamos." (Entrevista)
} 
recientes de la compañía puesto que se sigue concibiendo como un espacio de descubrimiento y exploración de nuevas técnicas teatrales que renueven el teatro de la isla. Para la crítica Amarilis Pérez Vera, "El trabajo con el cuerpo del actor es el pivot que favorece la imbricación entre cada una de las líneas de investigación de El Ciervo Encantado" (40), el cual constantemente mira hacia la herencia del neobarroco para explorar las posibilidades de explorar la intersección entre "lo cubano" y la simulación, la carnavalización, el choteo, la parodia, el camuflaje, etc. Las obras Pájaros de la playa, Visiones de la Cubanosofía y De donde son los cantantes siguen esta línea. Sin embargo, Departures y Arrivals son díptico de performances titulados que abordan el tema de la emigración cubana en un registro menos auto-celebratorio que las obras que exploran a la estética del neobarroco. El performance Arrivals se hizo a partir de unas grabaciones que recopiló Nelda Castillo. Las grabaciones son de las voces cubanas en la isla leyendo una lista de cosas que necesitan para que sus familiares que viven en el extranjero se las traigan. El audio se reproduce en el performance mientras Mariela intenta meter una enorme cantidad de objetos en sus maletas. ${ }^{14}$

Departures es la primera parte de este díptico que cuenta la emigración desde la perspectiva de los que se quedaron. Se estrenó en La Habana el 10 de febrero de 2017 y continuó presentándose hasta el 5 de marzo. ${ }^{15}$ No he tenido la oportunidad de asistir a una puesta en escena de Departures y, aunque si estuve en una función de Arrivals, los lenguajes teatrales de las dos obras son muy diferentes. Este análisis está construido a partir de documentos, conversaciones y videos. Agradezco a Mariela Brito y a Nelda Castillo, quienes me dieron acceso a una primera versión del video. Agradezco también a Lillian Manzor, quien compartió conmigo la versión que estoy utilizando para este análisis.

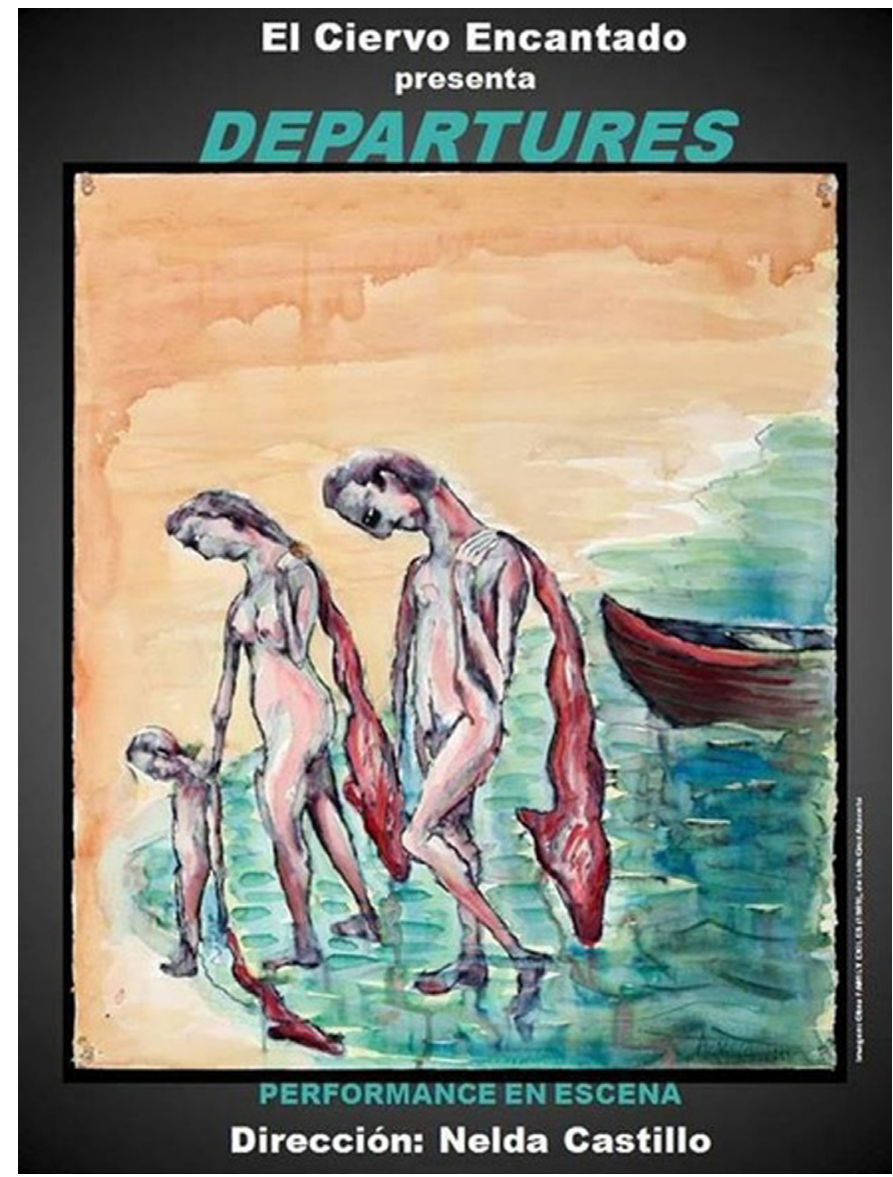

Programa de Departures. La Habana. Cuban Theater Digital Archive, 2018.

\footnotetext{
${ }^{14}$ Para más información sobre el proceso de creación de esta obra y sus implicaciones, se puede consultar mi entrevista a Nelda Castillo titulada, "Against Conventional Harmony."

${ }^{15}$ En octubre de ese mismo año, participó en el Festival Internacional de Teatro en la Habana. Recibió el Premio Villanueva de la Crítica, concedido por la Sección de Crítica Teatral de la Asociación de Artistas Escénicos de la UNEAC, y el Premio Mariposa. En el 2018, la obra se presentó en "The Greene Space" y en la "Sala La Nacional", ambas en Nueva York, en el "Open Arts Fest" en Miami y en el "Club Cubano" en New Jersey. En México, la obra se presentó en la "22 Muestra Estatal de Teatro" en Guadalajara y en el Museo Universitario del Chopo, en la Ciudad de México. Para este artículo, utilizaré el video de una puesta en escena de octubre del 2017, filmado por el Cuban Theater Digital Archive.
} 
Las notas al programa muestran la obra "Family Exiles" (1959), del pintor cubano americano Luis Cruz Azaceta (n. 1942), una representación del exilio centrada en el dolor corporal de la separación y la desposesión. Aunque la pintura está representando una llegada a un lugar nuevo, la posibilidad del inicio, las figuras humanas están cabizbajas, derrotadas. La representación de la costa también contribuye a la desesperanza puesto que es un no-lugar: no los recibe nadie, no hay nada más que arena. Cargan con unas cosas que parecen pedazos de carne en forma de la isla de Cuba ${ }^{16}$ y que podrían interpretarse como una versión de sí mismas que dejó de existir como algo vivo pero que cargan con ellos en sus espaldas. La lancha detrás de ellos es como si estuviera empujándolos hacia su nuevo destino y, al mismo tiempo, conecta con el imaginario de la llegada en balsa a los Estados Unidos, especialmente desde el Caribe.

El espacio teatral también reproduce la idea de la orilla y la desposesión. La audiencia, sentada en sus butacas en la sala de teatro de El Ciervo Encantado, es el reflejo de otra audiencia ausente que les mira desde fotografías, como si ellos mismos fueran el espectáculo al que asistieron. La audiencia ausente, entonces, habita en un no-lugar, en "La otra orilla", que es una canción que se escucha en la sala de teatro cuando Mariela se pone los audífonos. Por lo tanto, el límite entre el escenario y la audiencia es la orilla que marca la diferencia entre los que se quedaron en Cuba y los que se fueron. En ese sentido, las narraciones de Mariela, quien camina entre la audiencia presente y la audiencia ausente, son una manera de comunicar una historia común entre esas dos orillas.

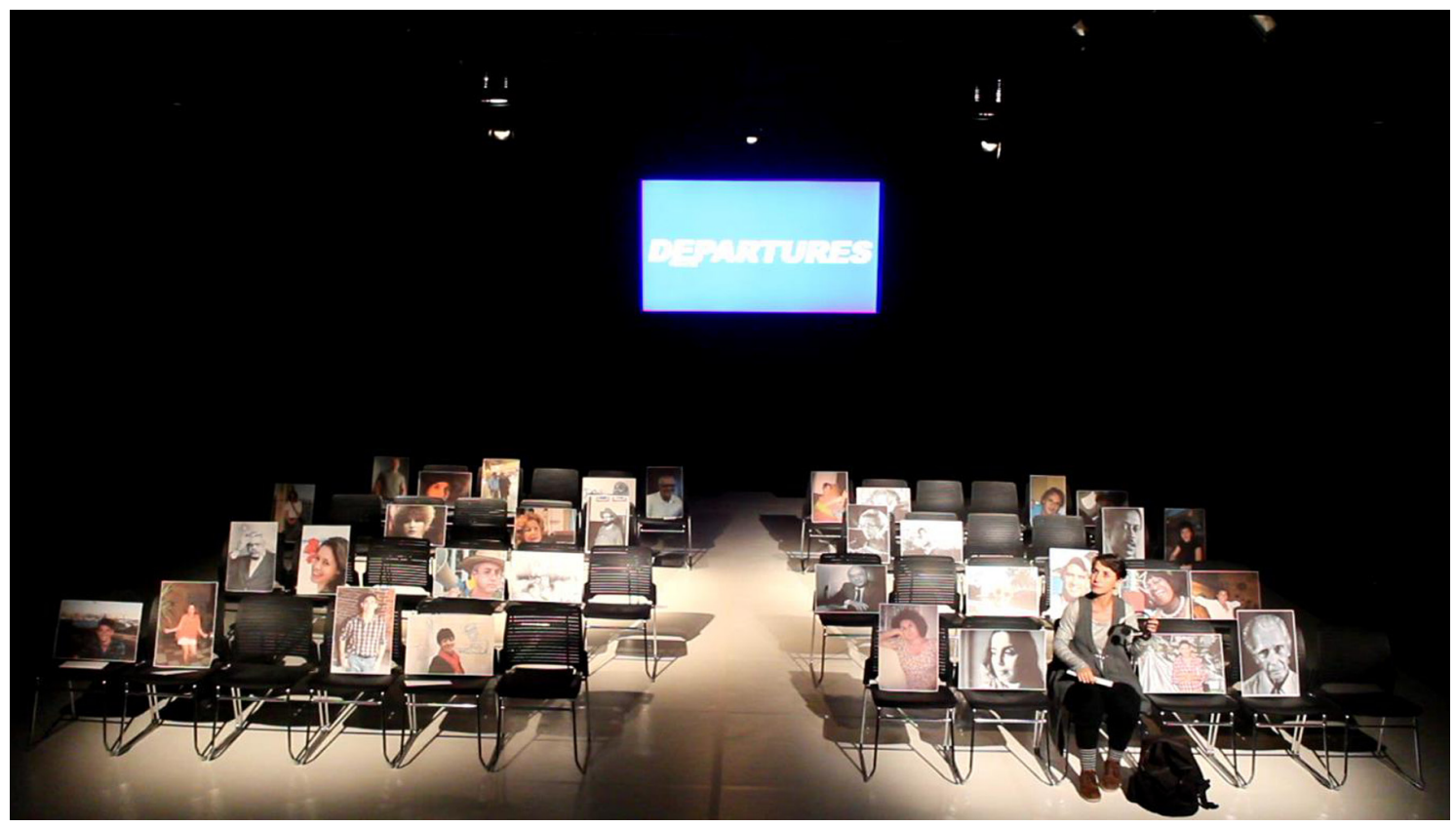

Fotografía del espacio escénico, Jaime Gómez Triana. Teatro En Cuba.

En la construcción del espacio escénico, Departures está borrando la distinción entre el yo y el otro puesto que la obra está creando momentos de comunicación entre Cuba y el no-lugar de los que emigraron. Este establecimiento y posteriormente, suspensión de las dicotomías marcan el testimonio de Mariela durante los actos de repudio.

Mariela presenta a la audiencia su testimonio personal sobre los actos de repudio en los que participó: el primero es el acto de repudio que ella hizo en contra de Papillo, su amigo; el segundo es el que realizan en contra su hermano porque Samuel, un amigo íntimo de él, había dejado correr el rumor de que se quería ir por El Mariel. En ambos casos, la vulnerabilidad del relato viene de una tensión entre las relaciones de pertenencia creadas por la amistad, es decir, desde la intimidad y la proximidad, y las relaciones de pertenencia creadas por el estado cubano, que incluye las creadas por los actos de servicio y lealtad a la revolución de 1959. Desde la perspectiva de Jean-Luc Nancy "mi país" no corresponde exclusivamente a la nación, sino que es una cuestión de pertenencia: un conjunto de relaciones que sostienen, corresponden y tienen sentido con lo que somos:

\footnotetext{
${ }^{16}$ Agradezco a Lillian Manzor, quien me hizo la observación sobre la forma de la isla en lo que llevan cargando los personajes.
} 
To belong" means "to hold to [tenir à]," both in the sense of "being attached to" and in the sense of "having one's own pertinent relation to." "My country" is for me a matter of holding [la tenue] (I hold to it, it holds me, it holds together) and pertinence (it corresponds, it responds, it makes sense at the very least as a resonance). That is why "my country" can be, at the same time and with no contradiction, a town and a nation, a region, a neighborhood, a city. (53)

Nancy asegura que no hay contradicción entre estos niveles de pertenencia entre la nación y los otros paisajes geográficos que generan pertenencia. Sin embargo, Departures demuestra que esto no era posible durante los momentos más polarizados de las políticas en Cuba. Esta es la tensión que los personajes no pueden navegar y, en consecuencia, el origen del dolor de la no-pertenencia y la exclusión. Aunque el testimonio de la actriz incluye al sujeto que repudia (ella misma) y al sujeto repudiado (su hermano, su casa), en ambas situaciones esto representa una pérdida de las relaciones de barrio, amistad y proximidad que ya existían antes de que la revolución intentara reconceptualizarlas de otra manera.

Mariela narra el acto de repudio que su escuela la llevó a hacerle a Papillo:

En 1980, yo tenía once años. Estaba en el sexto grado de la primaria. Y en la escuela tenía un gran amigo. Nos sentamos juntos desde primer grado. Y nuestra amistad estaba determinada por la fatalidad. Él era gordo, yo era gorda y bizca y de alguna estas desgracias nos unieron de manera muy fuerte. Y nos protegíamos del escarnio del resto de la escuela. (Notas al programa)

Cuando afirma que se sentaban juntos desde el primer grado, Mariela destaca la condición de proximidad, pertenencia y apoyo mutuo. El relato de amistad enfatiza la posición vulnerable en la que se encuentran ambos niños desde el inicio de la primaria. A diferencia de Diez millones, ellos no están marcados por la expresión de género de su lenguaje corporal, sino directamente por la constitución de su cuerpo. En una sociedad en la que el modelo de revolucionario de un guerrillero fuerte y capaz, es decir, una representación ideal del ableismo, el sobrepeso y el estrabismo son características que se entienden como carencias, como imposibilidades de actuar. Por otra parte, "el escarnio del resto de la escuela", es como una especie de repudio permanente, enfatizando más la relación entre las instituciones educativas y la manifestación pública del odio que se continúa reproduciendo en otras estructuras de la sociedad.

El relato testimonial continúa con el relato de repudio frente a casa de Papillo coordinado por la escuela a donde asistían:

Ese día, iríamos a casa de Papillo a hacer un acto de repudio. Una casa donde yo había estado la tarde anterior. Haciendo la tarea, comiendo las meriendas que nos preparaba su mama, jugando, con Papillo, su hermana. Pero ahora estaba fuera. Dentro de la turba. Y viviendo dos terrores. El terror de que las maestras vieran que yo estaba llorando, que no gritara con fuerza las consignas, los insultos, que no acababa de tirar el huevo que me habían puesto en la mano. Y el terror de pensar en Papillo, si estaba asustado, si se había metido debajo de la cama o dentro de un escaparate. Y que pasaría si la turba rompía la puerta y entraba en la casa. Qué haría Papillo. Y que haría yo. (Notas al programa)

Al igual que en Diez Millones, la obra crea la dicotomía del "dentro", que representa los lazos familiares y de amistad, y el "afuera", donde está la turba que, a través del performance público del odio, quiere enfatizar las relaciones de antagonismo durante la revolución. La niña expresa las contradicciones que está viviendo a través del acto de llorar puesto que está destruyendo sus dos mundos conocidos: el de la escuela, que ya había presentado como un ambiente hostil, y el de la casa de Papillo, donde encontraba refugio del acoso escolar que sufría a causa de su apariencia física. La línea "el terror de que no acabara de lanzar el huevo que me habían puesto en la mano", habla directamente sobre la responsabilidad que la niña tuvo en estos momentos. Por esta razón, el marco de memoria que está creando Departures para la audiencia tramita el trauma del repudio suspendiendo, la búsqueda de justicia o una denuncia, sin poner en duda la validez de la verdad testimonial.

El conflicto que está contando Mariela es el de ser una niña que, por causas ajenas a ella misma, vive diferentes formas de repudio y exclusión en las que pasa de ser la que repudia, a ser repudiada. Lo primero que la actriz menciona es el hostigamiento de sus compañeros de la escuela. Después, la llevan a hacerle un acto de repudio a su amigo y, algunos días después, cuando va a verlo a su casa, el padre de Papillo la insulta y no le abre la puerta. Finalmente, hacen un acto de repudio a su hermano y al día siguiente, a su casa. Sin importar que ella sea la que repudia o la repudiada, todos los casos expresan una pérdida del barrio y la amistad. 
El testimonio de Mariela continua con la historia de su hermano y el repudio que hicieron frente a su casa:

En 1980, mi hermano tenía 22 años y en una conversación muy intima entre amigos de mucha confianza, mi hermano preguntó, como es que la gente se puede ir en esos botes. Qué hacen para montarse en esos barcos si no tienen familia para venirlos a buscar. (Notas al programa)

El relato comienza de la misma manera que comienza el testimonio donde ella era protagonista: primero destaca el año, la edad y el contexto de amistad en el que se encontraba. La repetición de la estructura narrativa acentúa la excepcionalidad de esos años, la importancia de vivirlo desde una perspectiva desde la que no se comprende completamente lo que está pasando y el origen del sentimiento de pérdida que involucra el acto de repudio.

Más adelante, Mariela explica que, entre esa gente de mucha confianza, estaba el mejor amigo de su hermano, quien fue el que comunicó a las autoridades esta conversación como prueba de que estaba pensando irse por el Mariel. La actriz recuerda la relación que existía entre ellos cuando eran niños: "Se criaron juntos, crecieron juntos y sé que se querían muchísimo. Samuel, que es o era el nombre de este amigo, siempre estaba en mi casa. Tenía una sonrisa preciosa. Siempre se sabía cuando Samuel estaba. O al menos lo sabía yo. Porque podía hacer con Samuel todo lo que mis hermanos no querían hacer conmigo." Por lo tanto, el conflicto entre el barrio y la nación, entre la amistad y la revolución, se repite nuevamente. La necesidad de repudiar o ser repudiado involucra una pérdida para los tres personajes.

Posteriormente, Mariela narra el relato del acto de repudio que le hicieron a su hermano, que era profesor de deportes en la universidad:

fueron al aula, donde estaba impartiendo una clase, lo sacaron, y todos los trabajadores, alumnos de esa escuela, le gritaron, lo ofendieron, lo patearon, lo pincharon con jabalinas. Lo escupieron y lo arrastraron desde la escuela, unos kilómetros hasta la salida de la ciudad, en donde lo dejaron tirado al lado de la carretera. (Notas al programa)

Este es el momento de más intensidad en la obra porque es cuando el testimonio llega a sus límites con respecto a la capacidad que tienen las palabras para representar el dolor de la pérdida. No hay cambios ni en el volumen ni en la tonalidad de la voz de Mariela. Tampoco asistimos a un relato lleno de detalles sobre los eventos, por lo tanto, no es una narración que intente hacer una recreación de la realidad para transportar a la audiencia a ese momento de la historia cubana. Las palabras resultan informativas, con muchos silencios entre ellas revelando que es precisamente el dolor de los eventos lo que no se puede representar a través del lenguaje. En esos silencios y a través de los gestos de la actriz, es posible para la audiencia empezar a imaginar la dimensión emocional de estos actos públicos de odio. Por ejemplo, cuando hacen un acto de repudio frente a su casa, al día siguiente del acto de repudio que le hicieron a su hermano, Mariela está en su casa y afirma: "Desde adentro es, aterrador."

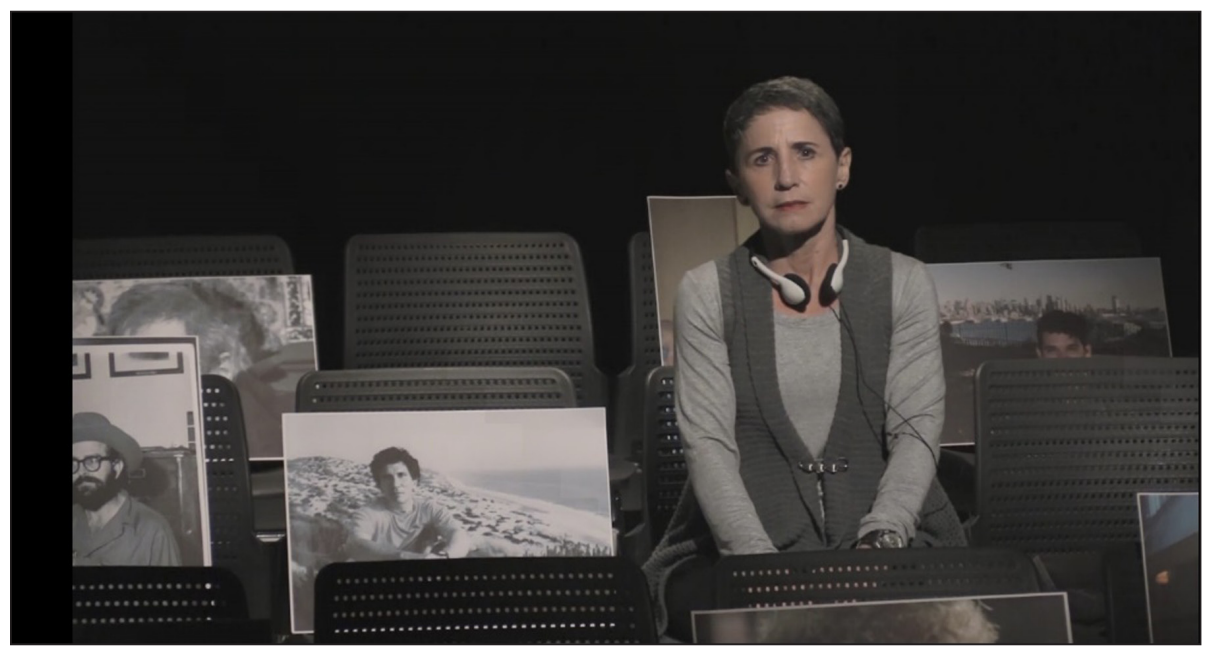

Fotografía de Jaime Gómez Triana. Teatro en Cuba. 
La dimensión archivística de Departures viene de las cartas personales que le enviaron a Mariela, de las fotos, de libros de memorias, por ejemplo, Necesidad de libertad de Reinaldo Arenas, etc. Más que una serie de documentos que intenten promover la necesidad de una versión única de cómo fueron los actos de repudio, el archivo que presenta Departures tiene la intensión de hacer presente la historia de las pérdidas personales. La actriz afirma: "Nunca más vi a Papillo. Nunca más supe de él." "Nunca más supe de Samuel." De una bolsa plástica, saca una foto y explica que, en esa foto, están en un potrero, a lado de su casa, aprendiendo a empinar papalote y entrega la foto a la audiencia. Se pone los audífonos y se escuchan los Beatles, "All You Need is Love".

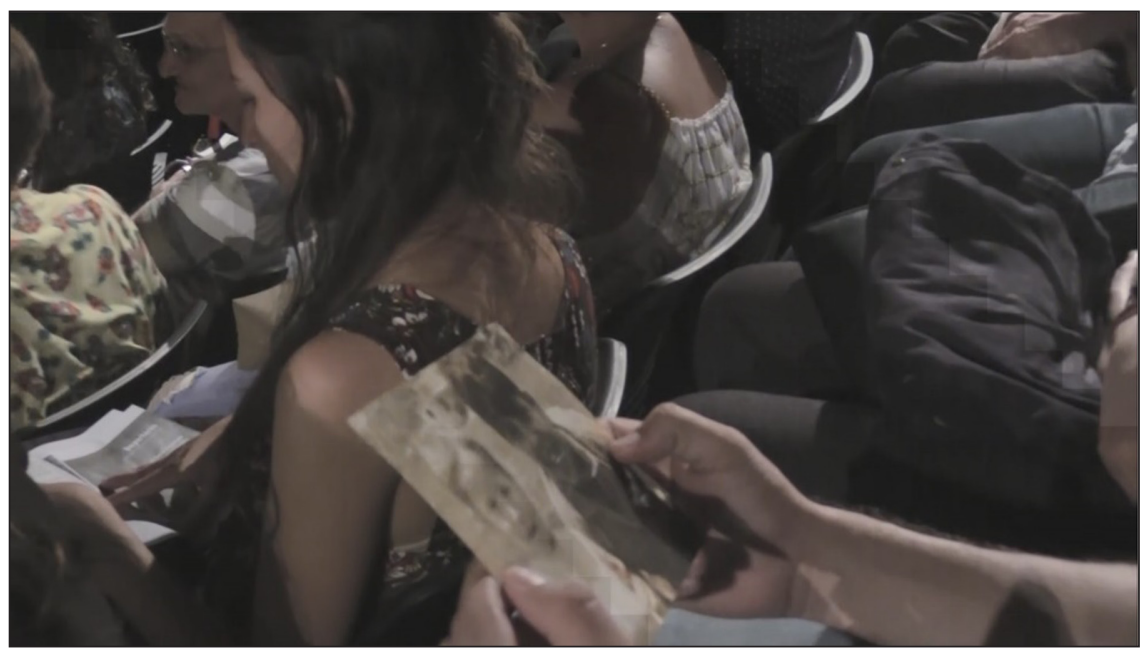

Foto de Mariela y Samuel que la audiencia pasa de mano en mano mientras escucha "All You Need is Love". Archivo personal.

El archivo de Departures es una recuperación de las relaciones de amistad, de barrio y de pertenencia que se perdieron durante los actos de repudio de 1980. A diferencia de Diez Millones, en donde las fotos nunca se ven y sirven para establecer una desconexión con el pasado, Departures la utiliza para revaluarla desde el contexto de la Cuba del siglo XXI. En cambio, los relatos orales son más un recuento informativo de los eventos de aquellos años. Por ejemplo, en el blog de El Ciervo Encantado, se afirma:

He necesitado ver Departures para saber que existió algo llamado "campamentos de apátridas", donde quienes solicitaban la salida del país debían esperar, trabajando en la agricultura, en régimen semimilitar. Y como yo, muchos nacidos en las décadas de los 70, los 80, los 90 o el presente siglo, escuchan sobre estas "partidas" enmudecidos, atónitos.

\section{Conclusiones}

La vulnerabilidad como una condición desde la cual se pueden negociar las relaciones de opresión y dominación en el contexto de la Cuba revolucionaria es una constante en las producciones culturales cubanas que han comenzado a hablar de los actos de repudio. La vulnerabilidad estratégica es un recurso que permite enmarcar los actos de repudio como una pérdida más que como una búsqueda de justicia, la responsabilidad o la relación entre este dolor y las pautas de la comunidad revolucionaria durante los años setenta. Por otra parte, reescenificar los actos de repudio implica irremediablemente una reflexión ética sobre la continuidad y la actualidad del repudio en Cuba. ¿Es posible, entonces, hablar de una memoria histórica? ¿Los actos de repudio siguen siendo una estrategia válida para fundar comunidad en la Cuba del siglo XXI? ¿Es el dolor que causaron, un punto de partida para generar una comunidad más allá del comunismo?

\section{Competing Interests}

The author has no competing interests to declare.

\section{References}

Arenas, Reinaldo. Antes que anochezca. Tusquets, 1994.

Calviño, Manuel. "Breve ensayo sobre la psicología en Cuba". Revista Cubana de Psicología. Número especial conmemorativo, 2008, pp. 9-18. 
Celdrán Carlos. "Diez Millones." Cuba Queer: 27 textos para el teatro. Edited by Ernesto Fundora. Editorial Hypermedia, 2017.

---. Diez Millones. www.argosteatro.cult.cu/10MILLONES/10millones.html.

Cruz Azaceta, Luis. Family Exiles. 1989. Accessed Nov 9, 2021. www.luiscruzazaceta-art.com/selected-drawings/ eck1yozic6exc4gios5p5fmjfi2sx3.

De Ferrari, Guillermina. Vulnerable States: Bodies of Memory in Contemporary Caribbean Fiction. U of Virginia Press, 2012.

Del Risco, Enrique. “Diez Millones: memoria y perdón”. Hypermedia Magazine. Abril 24, 2017.

Departures. Nelda Castillo, dir. El Ciervo Encantado y Cuban Theater Digital Archive, video eds. Sala El Ciervo Encantado, Habana. Octubre 2017.

"Diez Millones." Revista Conjunto, no. 185, pp. 108-109.

El Ciervo Encantado. "Departures." El Ciervo Encantado: Un espacio de indagación teatral desde la Cuba actual, www.elciervoencantado.blogspot.com/p/blog-page_28.html.

Espinosa Mendoza, Norge. Cuerpos de un deseo diferente: Notas sobre homoerotismo, espacio social y cultura en Cuba. Ediciones Matanzas, 2012.

Gusanos. Ailer González y Antonio G. Rodiles, dir. Estado de SATS, 2014.

"La posicion de Cuba." Granma, 7 de abril, 1980, p. 1.

Lambe, Jennifer L. Madhouse Psychiatry and Politics in Cuban History. U of North Carolina Press, 2016. DOI: https://doi.org/10.5149/northcarolina/9781469631028.001.0001

Madero, Abel Sierra. "'El trabajo is hará hombres': masculinización nacional, trabajo forzado y control social en Cuba durante los años sesenta." Cuban Studies, no. 44, 2016, pp. 309-349. DOI: https://doi. org/10.1353/cub.2016.0016

Manzor, Lillian y Jaime Gómez Triana. Un altar en los manglares. "Entrevista con Nelda Castillo y Mariela," 2012, ciervoencantado.tome.press/chapter/ii-entrevista-con-nelda-castillo-y-mariela/?lang=es.

Nancy, Jean-Luc. The Sense of the World. Translated by Jeffrey S. Librett. Minnesota UP, 1997.

Pérez Vera, Amarilis. Otro heredero. Elementos neobarrocos en los espectáculos de El Ciervo Encantado. Ediciones Alarcos, 2013.

Porbén, Pedro, La revolución deseada: prácticas culturales del hombre nuevo en Cuba. Verbum, 2014.

Rigney, Ann. "Remembering Hope: Transnational Activism beyond the Traumatic." Memory Studies, vol. 11, no. 3, July 2018, pp. 368-380. DOI: https://doi.org/10.1177/1750698018771869

White, Bretton. Performance and Queerness in Contemporary Cuba. UP of Florida, 2020.

How to cite this article: Martínez Alvarez, M 2021 El teatro y la memoria emergente de El Mariel: Testimonio, vulnerabilidad y archivo. Anthurium, 17(2): 8, 1-16. DOI: https://doi.org/10.33596/anth.454

Published: 14 December 2021

Copyright: (c) 2021 The Author(s). This is an open-access article distributed under the terms of the Creative Commons Attribution 4.0 International License (CC-BY 4.0), which permits unrestricted use, distribution, and reproduction in any medium, provided the original author and source are credited. See http://creativecommons.org/licenses/by/4.0/. 